DOI: $10.15193 /$ zntj/2018/114/228

EWA BIAŁECKA-FLORJAŃCZYK, NATALIA SOBOROWSKA, ANNA KUNDYS

\title{
BARWNIKI SPOŻYWCZE W PRODUKTACH DLA DZIECI NA PODSTAWIE DEKLARACJI PRODUCENTÓW
}

\begin{abstract}
Streszczenie
Barwniki używane w produktach żywnościowych dzieli się na naturalne i syntetyczne. Stosowanie tych ostatnich wzbudza wiele kontrowersji ze względu na ich potencjalnie szkodliwy wpływ na organizm człowieka. Szczególne obawy dotyczą niekorzystnego wpływu barwników syntetycznych na zachowanie i zdrowie dzieci. Celem pracy była ocena składu wybranych produktów dla dzieci pod względem użytych substancji barwiących. Przegląd związków barwnych stosowanych w słodyczach i napojach przeznaczonych dla dzieci wykonano na podstawie deklaracji producentów 107 produktów, wśród których były: napoje, żelki, lizaki, cukierki i dekoracje cukiernicze. Wyniki przedyskutowano w kontekście toksyczności barwników używanych w przemyśle spożywczym. Ponadto przedstawiono krótką charakterystykę substancji barwiących znajdujących się w badanych produktach, ze szczególnym uwzględnieniem barwników syntetycznych.

Stwierdzono, że producenci badanych wyrobów przeznaczonych dla dzieci stosują przede wszystkim ekstrakty i koncentraty pochodzenia roślinnego, ewentualnie barwniki naturalne bądź identyczne z naturalnymi. Użycie barwników syntetycznych jest ograniczone zgodnie z zaleceniami Europejskiego Urzędu ds. Bezpieczeństwa Żywności (EFSA). Żaden z trzech organicznych barwników syntetycznych zadeklarowanych przez producentów na etykietach żywności dla dzieci nie należał do grupy tzw. „barwników z Southampton”. Mianem tym określa się barwniki (żółcień chinolinową - E104, tartrazynę - E102, żółcień pomarańczową FCF - E110, azorubinę - E122, czerwień koszenilową - E124 i czerwień Allura AC E129), w stosunku do których istnieją przesłanki o niekorzystnym wpływie na aktywność i skupienie uwagi u dzieci.
\end{abstract}

Słowa kluczowe: produkty dla dzieci, barwniki naturalne i sztuczne, ocena bezpieczeństwa, deklaracje producentów na etykietach

Prof. dr hab. inż. E. Biatecka-Florjańczyk, inż. N. Soborowska, dr inż. A. Kundys, Katedra Chemii, Wydz. Nauk o Żywności, Szkoła Gtówna Gospodarstwa Wiejskiego w Warszawie, ul. Nowoursynowska 159 C, 02-776 Warszawa. Kontakt: ewa_bialecka_florjanczyk@sggw.pl 


\section{Wprowadzenie}

Barwa jest jedną z podstawowych cech sensorycznych żywności i w istotnym stopniu wpływa na odbiór produktu przez konsumenta. Barwniki oznaczane są na etykietach symbolem E i numerami od 100 do 199. Oznakowanie jest wprowadzone zgodnie z międzynarodowym systemem numerycznym. Ma on pomóc w uporządkowaniu dodatków do żywności oraz zapewnić szybszą ich identyfikację na rynku międzynarodowym. Dodatki oznaczone symbolem E są przebadane pod względem toksykologicznym, uznane za bezpieczne i dozwolone do stosowania do wszystkich produktów w przemyśle spożywczym przez Europejski Urząd ds. Bezpieczeństwa Żywności (EFSA) [18]. Analiza toksyczności dodatków polega na wykonaniu szeregu badań z zakresu rakotwórczości, genotoksyczności, toksyczności rozwojowej i reprodukcyjnej oraz metabolizmu. Na podstawie tej analizy i dokumentacji związku (obejmującej chemiczną identyfikację, przebieg produkcji, metody analizy i reakcje substancji w żywności) EFSA ustala ADI (Acceptable Daily Intake), czyli dopuszczalne dzienne spożycie, które oznacza maksymalną dawkę ( $\mathrm{mg} / \mathrm{kg}$ masy ciała) niewywołującą żadnych negatywnych skutków dla zdrowia, jaką człowiek może spożywać codziennie przez całe życie [10]. Dopuszczalne dzienne spożycie ustalane jest przy zachowaniu marginesu bezpieczeństwa (100 razy niższe) w stosunku do dawki NOAEL (no observable adverse effect level), oznaczającej maksymalną dawkę, przy której nie zaobserwowano żadnych negatywnych skutków [11]. Powinno ono uwzględniać prawdopodobną dawkę dzienną pochodzącą ze wszystkich źródeł.

Zgodnie z Rozporządzeniem Parlamentu Europejskiego 1333/2008 [19], terminem barwniki określa się: „substancje nadające lub przywracające żywności barwę, obejmujące naturalne składniki żywności i naturalne źródła, które w normalnych warunkach ani nie są same spożywane jako żywność ani nie są stosowane jako typowe składniki żywności." Mogą to być zatem preparaty uzyskane z surowców naturalnych w wyniku selektywnej ekstrakcji pigmentów. Ze względów aplikacyjnych wśród barwników spożywczych można wyodrębnić dwie grupy [18]:

- barwniki spożywcze o limitowanym dopuszczalnym dziennym spożyciu, których maksymalne dopuszczalne poziomy zawarte są w odpowiednich przepisach (przede wszystkim barwniki syntetyczne),

- barwniki stosowane zgodnie z zasadą quantum satis (obejmujące przede wszystkim barwniki pochodzenia naturalnego), które nie mają określonego maksymalnego poziomu użycia i powinny być używane w dawce najniższej, niezbędnej do osiągnięcia zamierzonego efektu technologicznego, przy zastosowaniu zasad dobrej praktyki produkcyjnej.

Barwniki naturalne, których źródłem jest głównie materiał pochodzenia roślinnego, a w szczególnych przypadkach zwierzęcego, są akceptowane przez konsumentów i z reguły nie budzą zastrzeżeń zdrowotnych $[17,23]$. Ich struktura chemiczna powo- 
duje, że są często niestabilne i mają niewielką odporność na działanie światła, temperatury, metali oraz tlenu. Mogą zatem ulegać przemianom podczas przetwarzania i magazynowania. Produkcja barwników naturalnych polega przede wszystkim na ekstrakcji pożądanego związku z materiału biologicznego, a ich formą handlową są wyciągi, ekstrakty lub koncentraty - roztwory wodne lub olejowe, emulsje, zawiesiny, a także preparaty suche [20]. Dlatego taka forma dodatku do żywności składa się z reguły z wielu różnych substancji, których działanie także należy rozważyć - np. barwniki pochodzenia mikrobiologicznego mogą zawierać mikotoksyny [1]. W związku z tendencją do ograniczania użycia w przemyśle spożywczym sztucznych (syntetycznych) substancji barwiących, wzrasta zapotrzebowanie na barwniki naturalne, ewentualnie identyczne $\mathrm{z}$ naturalnymi, otrzymywane $\mathrm{w}$ wyniku syntezy chemicznej (jak betakaroten lub kantaksantyna). Duże nadzieje związane są także z pozyskiwaniem substancji barwiących - na przykład likopenu czy ryboflawiny - z hodowli takich mikroorganizmów, jak bakterie, grzyby czy też algi [1].

Do barwników syntetycznych zalicza się zarówno związki organiczne, jak i nieorganiczne, przy czym te ostatnie nie odgrywają dużej roli w barwieniu żywności. Stosowane są głównie do barwienia powierzchniowego (np. w cukiernictwie) [20]. Syntetyczne barwniki organiczne to przede wszystkim związki azowe, trifenylometylowe, indygoidowe i chinolinowe $[12,14]$. W porównaniu z naturalnymi substancjami barwiącymi mają one wiele zalet, takich jak: standardowa i większa niż w przypadku barwników naturalnych moc barwienia, większa odporność na warunki zewnętrzne (temperaturę, światło, $\mathrm{pH}$ ) i niższa cena $\mathrm{w}$ porównaniu $\mathrm{z}$ barwnikami pochodzenia naturalnego. W przeciwieństwie do ekstraktów roślinnych są to ponadto jednorodne związki chemiczne. Stosowanie syntetycznych dodatków do żywności wzbudza jednak u konsumentów wiele kontrowersji ze względu na ich potencjalnie szkodliwy wpływ na organizm człowieka [23]. Szczególnie wiele dyskusji wywołała już w latach 70. ubiegłego wieku hipoteza o powiązaniach pomiędzy predyspozycjami do ADHD i obecnością syntetycznych dodatków do żywności w diecie dzieci amerykańskich, wysunięta przez pediatrę i alergologa dra Beniamina Feingolda [7]. Zgodnie z jego doniesieniami, po wyeliminowaniu $\mathrm{z}$ diety syntetycznych dodatków stan ponad połowy badanych dzieci uległ poprawie. W badaniach Feingolda zwrócono także uwagę na dodatkowy negatywny wpływ pochodnych kwasu acetylosalicylowego obecnego w wielu popularnych owocach i warzywach.

Problem zasygnalizowany przez Feingolda jest wciąż tematem wielu publikacji, ponieważ nie zawsze uzyskuje się jednoznaczne rezultaty $[2,8,14,22]$. Są one w dużym stopniu zależne od zastosowanej techniki badawczej (ślepa próba, podwójna ślepa próba), od uwarunkowań społecznych, a także wieku dzieci (młodsze wykazywały większą wrażliwość) [13]. Szczególnie w pierwszym dziesięcioleciu XXI wieku powrócono do tematu, a znaczny rozgłos zyskały badania McCann i wsp. [16], którzy na 
przykładzie dwóch grup dzieci - 3-letnich oraz 8- i 9-letnich stwierdzili, że w pewnych przypadkach obecność w pożywieniu kilku poniższych barwników sprzyja nadaktywności. Badania dotyczyły żółcieni chinolinowej (E104), tartrazyny (E102), żółcieni pomarańczowej FCF (E110), azorubiny (E122), czerwieni koszenilowej (E124) i czerwieni Allura AC (E129). Barwniki te określa się mianem „barwników z Southampton” (autorzy tych badań byli pracownikami Uniwersytetu w Southampton) i są one pod szczególną obserwacją EFSA. Skutkiem powyższych badań było obniżenie przez EFSA dopuszczalnego dziennego spożycia niektórych barwników (żółcieni chinolinowej, żółcieni pomarańczowej i czerwieni koszenilowej), a także konieczność umieszczania na etykietach ostrzeżenia o potencjalnym wpływie na aktywność i skupienie uwagi u dzieci [11]. Oznaczenia analityczne wybranych 20 produktów (napojów i wyrobów cukierniczych) wykonane w 2011 roku umożliwiły stwierdzenie, że „barwniki z Southampton" były używane na poziomie niższym niż obowiązujące limity [10]. $\mathrm{Z}$ pewnością jednak wyeliminowanie $\mathrm{z}$ diety barwników syntetycznych nie można traktować jako panaceum na ADHD [13].

Poza żółcienią chinolinową wszystkie barwniki „grupy Southampton” należą do związków azowych, dlatego warto poświęcić nieco uwagi ich biodegradacji. LD50 w przypadku barwników azowych szacowana jest na poziomie $500 \div 2000 \mathrm{mg} / \mathrm{kg}$ masy ciała [15]. Z powodu intensywnej barwy używane są one w żywności w niewielkich ilościach, dlatego też jednorazowe przekroczenie tej dawki jest mało prawdopodobne. Ze względu na rozpuszczalność w wodzie barwniki azowe nie ulegają kumulacji w organizmie, są metabolizowane w wątrobie i wydalane z moczem. Obecność w cząsteczce dodatkowej grupy sulfonowej poprawia rozpuszczalność w wodzie i zmniejsza toksyczność barwników, a tym samym ułatwia wydzielanie z moczem ich metabolitów - wszystkie barwniki azowe z ,grupy Southampton” zawierają co najmniej dwie grupy sulfonowe. Ewentualne toksyczne efekty uboczne powodują raczej produkty degradacji barwników: związki azowe są metabolizowane do amin aromatycznych w wyniku redukcji z udziałem azoreduktaz z mikroflory jelitowej [3].

Inny przykład stanowi historia tartrazyny (E102, rys. 6a), dość rozpowszechnionego żółtego barwnika, za pomocą którego generuje się barwę zieloną w mieszankach $\mathrm{z}$ barwnikami niebieskimi. Stosuje się ją w postaci soli sodowych, potasowych lub wapniowych. Przy podaniu doustnym wchłanianiu ulega poniżej $5 \%$ związku, reszta jest wydalana w niezmienionej postaci przez nerki. Absorpcji ulegają głównie metabolity - kwas sulfanilowy i $\alpha$-amino- $\beta$-ketomasłowy, które powstają w niewielkiej ilości pod wpływem mikroflory żołądkowo-jelitowej. Na podstawie poprzedniej dokumentacji i późniejszych danych literaturowych EFSA w 2009 [21] potwierdził możliwość występowania pewnych reakcji nietolerancji tartrazyny, ale nie stwierdził jej działania rakotwórczego i nie znalazł powodu do podniesienia ADI ustalonego poprzednio na poziomie $0 \div 7,5 \mathrm{mg} / \mathrm{kg}$ masy ciała. Jednak w 2016 roku JECFA (Joint FAO/WHO 
Expert Committee on Food Additives) zwiększyła ten próg do $10 \mathrm{mg} / \mathrm{kg}$ masy ciała na bazie NOAEL $984 \mathrm{mg} / \mathrm{kg}$ w badaniach chronicznej toksyczności na szczurach. Stwierdzono jednak, że obecna ekspozycja populacji (nie tylko dzieci) na tartrazynę nie stanowi zagrożenia dla zdrowia [9].

\section{Material i metody badań}

Materiałem doświadczalnym były wybrane produkty spożywcze przeznaczone dla dzieci, dostępne w sieci sklepów Carrefour i Tesco w Warszawie w październiku 2016 roku i w styczniu 2017. Obejmowały one wyroby z działu słodyczy i napojów, w tym: 42 rodzaje żelków, 20 różnych napojów aromatyzowanych, 13 rodzajów lizaków, 18 rodzajów cukierków i karmelków oraz 14 typów dekoracji cukierniczych - w sumie 107 produktów. Analiza etykiet i deklaracji producentów na opakowaniach tych produktów dotyczyła ustalenia rodzaju użytych barwników. Oprócz konkretnych substancji barwiących często stosowane były wieloskładnikowe ekstrakty lub wyciągi roślinne (z kurkumy, marchwi purpurowej, papryki, owocu czarnego bzu i spiruliny) oraz koncentraty z roślin, w tym z owoców (jak: krokosz, jabłko, marchew, spirulina, batat, cytryna, czarna porzeczka, hibiskus, rzodkiewka, czarny bez, aronia, winogrona, pomarańcza, mango, marakuja, kiwi, malina), które nie są głównym przedmiotem poniższego opracowania - występują one w zestawieniach pod nazwą koncentratów owocowych, ekstraktów lub wyciągów - w zależności od sformułowań używanych przez producentów. Pewną trudność stwarzała także niejednolita nomenklatura stosowana przez różnych producentów na określenie tych samych barwników.

\section{Wyniki i dyskusja}

Wyniki dotyczące każdej grupy analizowanych produktów przedstawiono w formie wykresów (rys. 1 - 5).

W przebadanych 42 rodzajach żelków najczęściej stosowanym barwnikiem (poza ekstraktami i koncentratami owocowymi w 34 produktach) była kurkumina. Znajdowała się w deklaracjach producentów na 10 produktach. Na drugim miejscu odnotowano kompleksy miedziowe chlorofili i chlorofilin -9 produktów. Kolejnymi barwnikami były karoteny -6 produktów, karminy i antocyjany - po 4 produkty. Spośród organicznych barwników syntetycznych w 3 wyrobach użyty był błękit patentowy $\mathrm{V}$, błękit brylantowy FCF - w jednym produkcie oraz nieorganiczny barwnik - dwutlenek tytanu - również w 1 produkcie. Należy zaznaczyć, że w kilkunastu produktach nie zostały użyte żadne konkretne barwniki, tylko ekstrakty roślinne (rys. 1). 


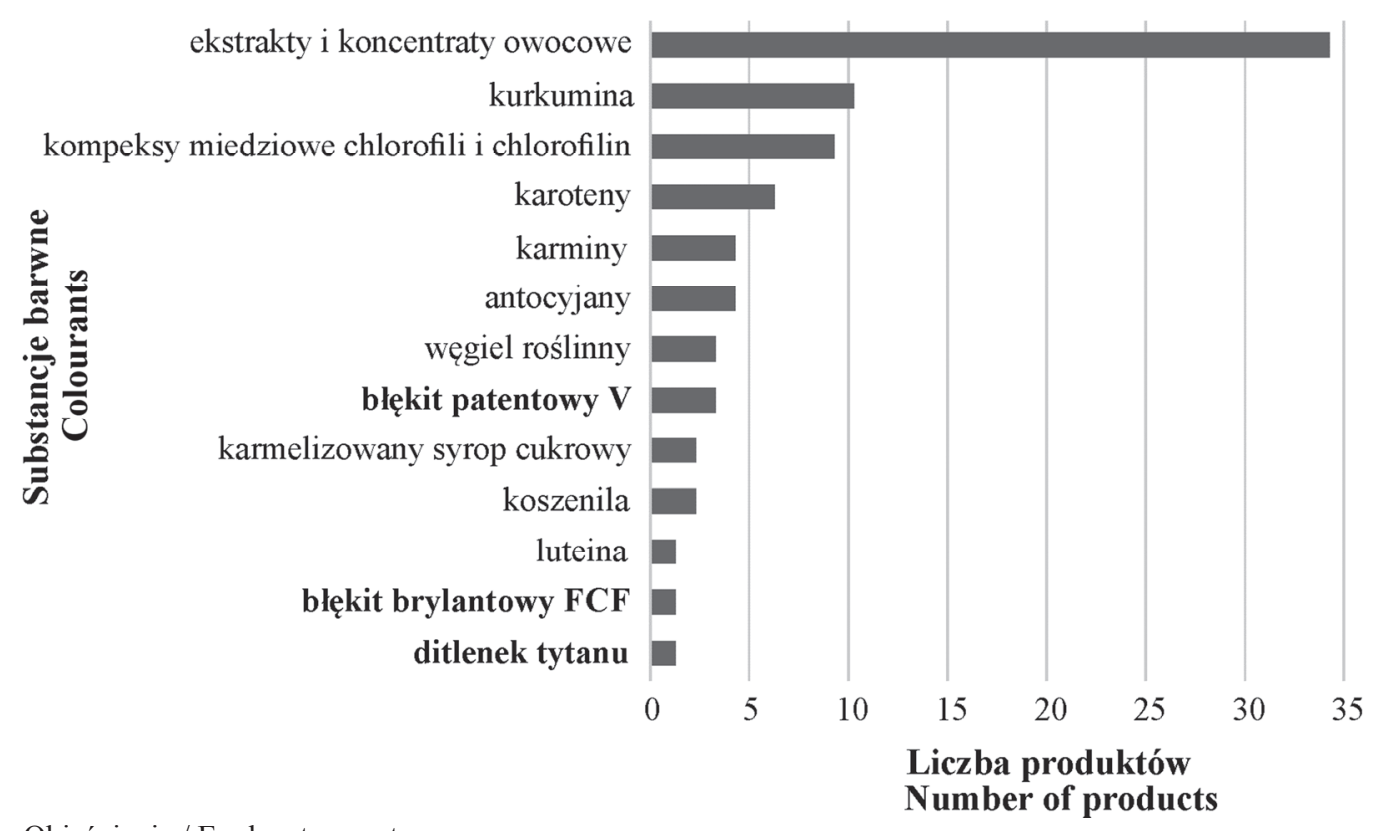

Objaśnienia / Explanatory notes:

Number of products

ekstrakty i koncentraty owocowe / fruit extracts and concentrates; kurkumina / curcumin; kompleksy miedziowe chlorofili i chlorofilin / copper complexes of chlorophylls and chlorophyllins; karoteny / carotenes; karminy / carmines; antocyjany / anthocyanins; węgiel roślinny / vegetable carbon; błękit patentowy $\mathrm{V} /$ patent blue V; karmelizowany syrop cukrowy / caramelised sugar syrup; koszenila / cochineal; luteina / lutein; błękit brylantowy FCF / brilliant blue FCF; ditlenek tytanu / titanium dioxide. Nazwy barwników syntetycznych pogrubiono / Names of synthetic colourants were written in bold.

Rys. 1. Rodzaje barwników i liczba badanych żelków z deklarowanym przez producentów użyciem tych barwników

Fig. 1. Types of colourants and number of analysed jellies in which, acc. to manufacturers' declarations those colourants were used

Wszystkie związki barwne, których użycie zostało zadeklarowane w przebadanych 20 napojach aromatyzowanych były pochodzenia naturalnego (lub identyczne z naturalnymi - tego rozróżnienia nie można zrobić na podstawie deklaracji producenta). W 5 produktach stwierdzono obecność kompleksów miedziowych chlorofili i chlorofilin, a karoteny i karmel amoniakalno-siarczynowy - w 2 produktach. W pojedynczych wyrobach znajdowały się kurkumina, antocyjany i beta-apo-8'-karotenal. Dominujące znowu okazały się koncentraty roślinne występujące w 9 produktach (rys. 2).

Po przeanalizowaniu 18 rodzajach karmelków i cukierków osiągnięto wyniki zbliżone do rezultatów produktów omówionych wyżej, tzn. stwierdzono zdecydowaną przewagę ekstraktów i koncentratów roślinnych. Jedynym barwnikiem syntetycznym okazała się indygotyna (rys. 3). 


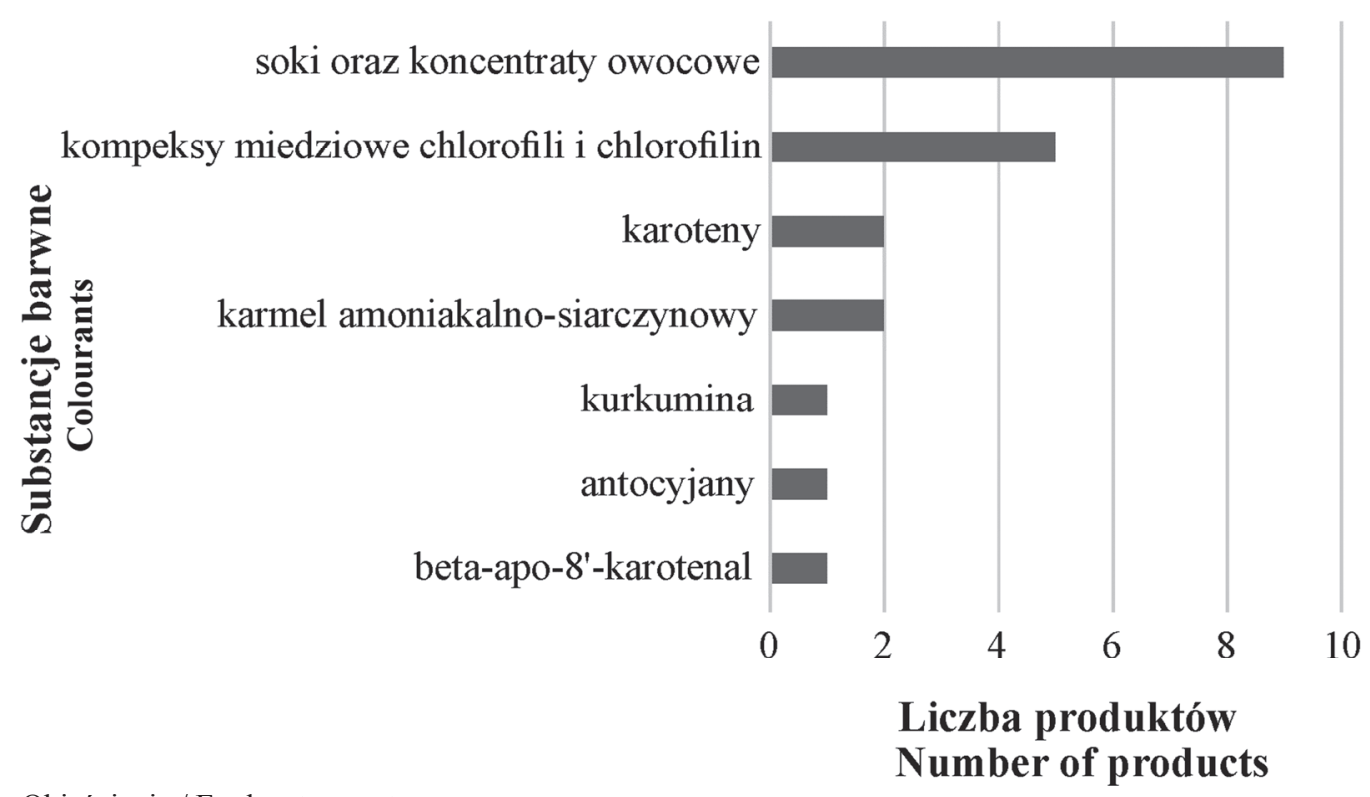

Objaśnienia / Explanatory notes: Number of products

soki oraz koncentraty owocowe / juices and fruit concentrates; karmel amoniakalno-siarczynowy / sulphite ammonia caramel; beta-apo-8'-karotenal / beta-apo-8'-carotenal. Pozostałe objaśnienia jak pod rys. 1. / Other explanatory notes as in Fig. 1.

Rys. 2. Rodzaje barwników i liczba badanych napojów z deklarowanym przez producentów użyciem tych barwników

Fig. 2. Types of colourants and number of analysed beverages in which, acc. to manufacturers' declarations those colourants were used

Substancje barwiące w lizakach przeanalizowano na podstawie deklaracji producentów zamieszczonych na opakowaniach 13 produktów. Do barwienia lizaków stosowano substancje naturalne lub identyczne z naturalnymi (betaninę, kurkuminę, karoteny, antocyjany). W stosunkowo niewielkim stopniu wykorzystywano koncentraty i wyciągi barwiące pochodzenia roślinnego (rys. 4).

W przypadku dekoracji cukierniczych producenci zadeklarowali na etykietach zastosowanie 2 barwników syntetycznych, z czego jeden używany był prawie tak często jak barwiące ekstrakty roślinne. Producenci zadeklarowali również obecność kilku pigmentów nieorganicznych: dwutlenku tytanu, tlenków i wodorotlenków żelaza, a także metalicznego glinu (rys. 5).

Reasumując, można stwierdzić, że na spektrum substancji barwiących zadeklarowanych przez producentów składają się głównie ekstrakty i koncentraty roślinne oraz barwniki pochodzenia naturalnego (bądź identyczne z naturalnymi) lub barwniki otrzymywane drogą przemiany chemicznej substratów roślinnych. W tab. 1. przedsta- 
wiono te barwniki, które zostały użyte w badanych produktach w postaci konkretnej substancji chemicznej lub należą do jednej grupy związków chemicznych.

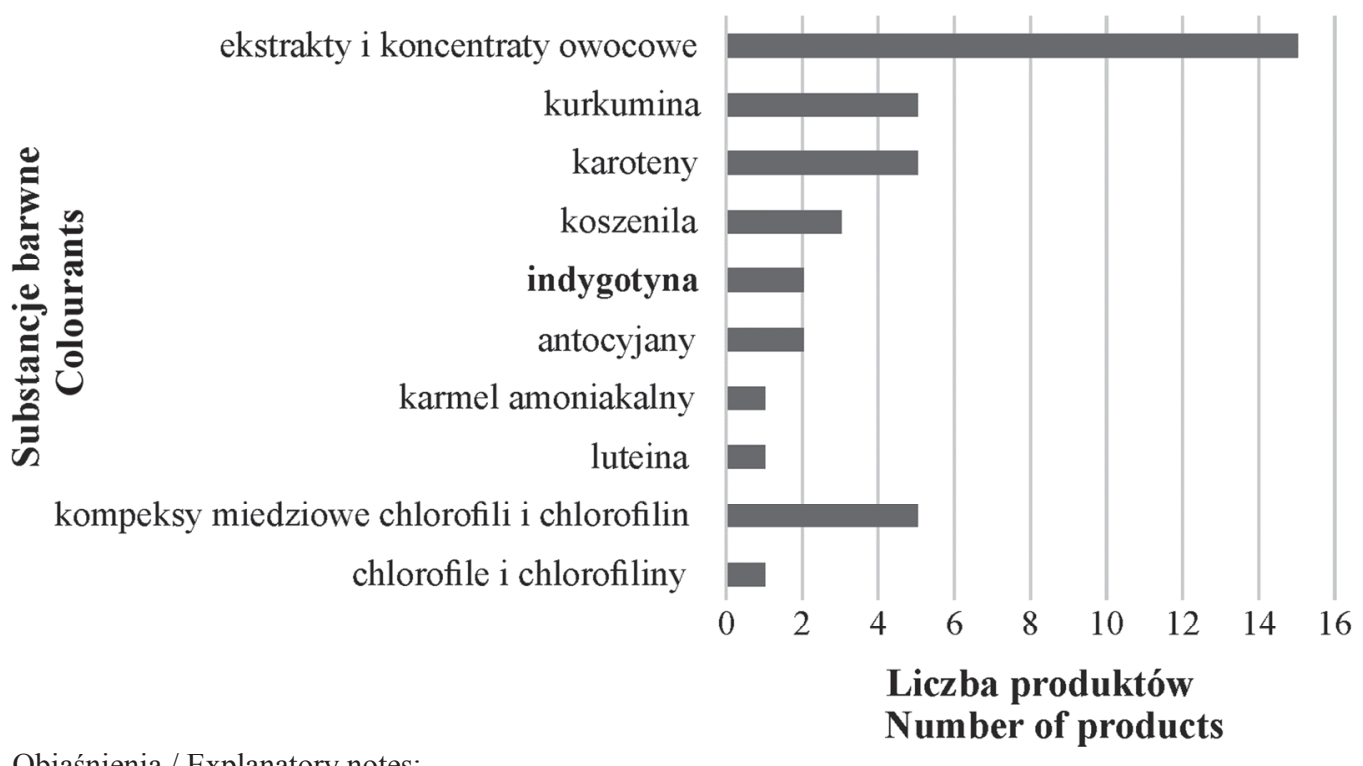

Objaśnienia / Explanatory notes:

indygotyna / indigotine; karmel amoniakalny / ammonia caramel; chlorofile i chlorofiliny / chlorophylls and chlorophyllins. Pozostałe objaśnienia jak pod rys. 1. / Other explanatory notes as in Fig. 1.

Rys. 3. Rodzaje barwników i liczba badanych cukierków i karmelków z deklarowanym przez producentów użyciem tych barwników

Fig. 3. Types of colourants and number of analysed candies and caramels in which, acc. to manufacturers' declarations those colourants were used

Syntetyczne barwniki, których obecność była deklarowana w badanych produktach to indygotyna, błękit patentowy V i błękit brylantowy FCF (rys. 6 b-d). Nie należą one wprawdzie do „barwników z Southampton”, ale ze względu na wyczulenie konsumentów na syntetyczne dodatki do żywności zostaną one omówione bardziej szczegółowo.

Niebieski barwnik indygotyna (indygokarmin, karmin indygo E132 - rys. 6b) to disulfonowa pochodną indyga, które obecnie produkowane jest przede wszystkim syntetycznie. Nie stwierdzono ujemnego działania indygotyny w badaniach toksyczności podostrej, reprodukcyjnej i chronicznej, a jej ADI wynosi $5 \mathrm{mg} / \mathrm{kg}$ masy ciała [6].

Błękit brylantowy FCF i błękit patentowy V należą do grupy barwników trifenylometylowych. Błękit patentowy V (E131 - rys 6c) używany jest w formie soli sodowej lub wapniowej. Według opinii EFSA z 2013 roku [22] rekomenduje się stosowanie błękitu patentowego $\mathrm{V}$ o czystości minimum 90 \% i zawierającego nie mniej niż $1 \%$ leukozasady. Barwnik nie wykazuje mutageniczności, genotoksyczności oraz toksycz- 
ności reprodukcyjnej i rozwojowej. ADI na poziomie $5 \mathrm{mg} / \mathrm{kg}$ masy ciała ustalono na podstawie dawki NOAEL wynoszącej $500 \mathrm{mg} / \mathrm{kg}$ masy ciała w badaniach chronicznej toksyczności u myszy. Generalnie w stężeniach, które są stosowane do barwienia żywności rzadko wywołuje skutki uboczne, ale może powodować wzrost wydzielania histaminy i stanowić przyczynę nasilenia objawów astmy i reakcji alergicznych. Może również wywoływać nadpobudliwość [5].

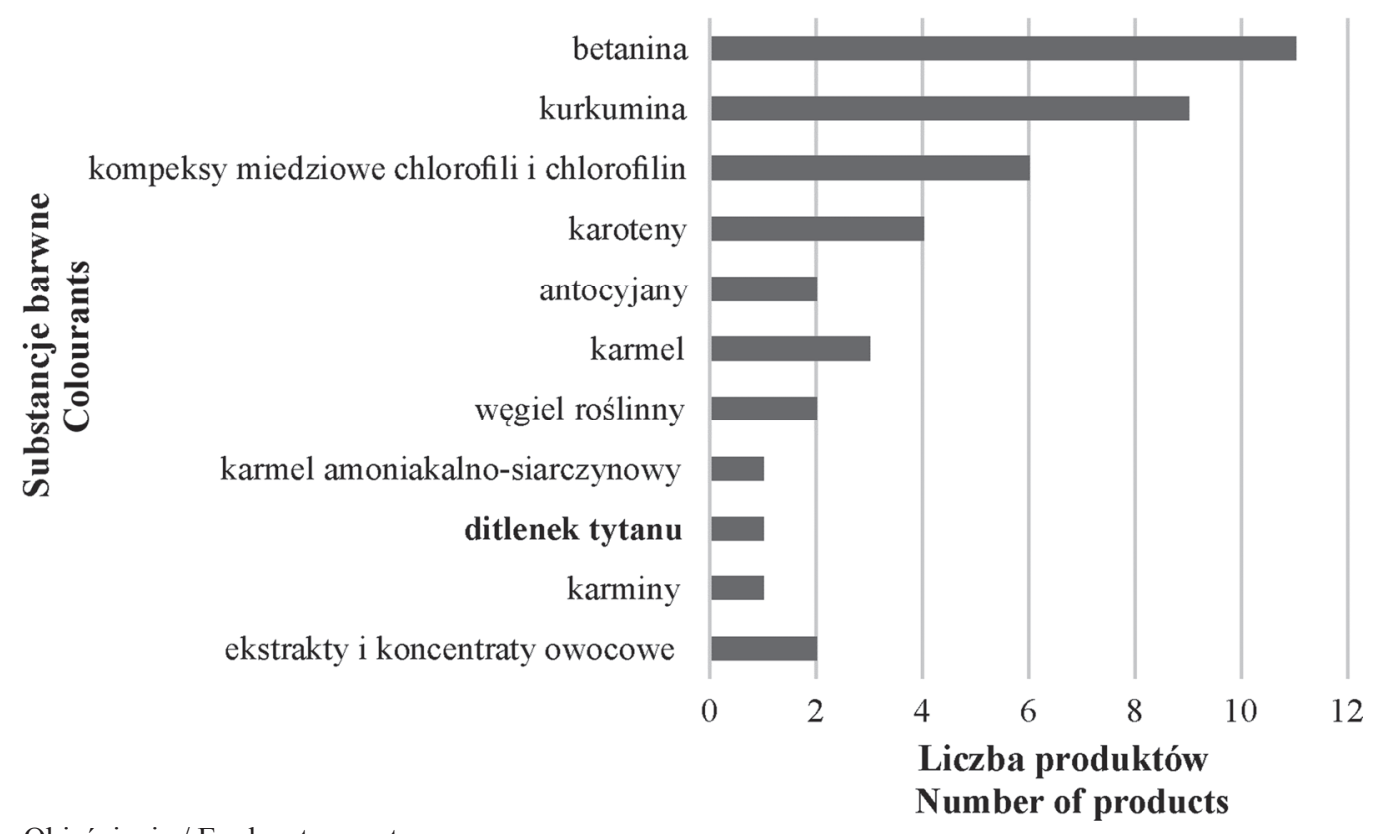

Objaśnienia / Explanatory notes:

Number of products

betanina / betanine; karmel / caramel. Pozostałe objaśnienia jak pod rys. 1. i 3. / Other explanatory notes as in Fig. 1. and 3.

Rys. 4. Rodzaje barwników i liczba badanych lizaków z deklarowanym przez producentów użyciem tych barwników

Fig. 4. Types of colourants and number of analysed lollipops in which, acc. to manufacturers' declarations those colourants were used

Błękit brylantowy FCF (E133) jest stosowany w postaci soli disodowej. Na podstawie dawki NOAEL wynoszącej $631 \mathrm{mg} / \mathrm{kg}$ masy ciała w badaniach chronicznej toksyczności u myszy ustalono ADI na poziomie $6 \mathrm{mg} / \mathrm{kg}$ masy ciała. Nie jest kancerogenny i genotoksyczny, a w wyniku badań związku zawierającego izotop węgla ${ }^{14} \mathrm{C}$ stwierdzono, że jest w $95 \%$ wydalany z kałem w niezmienionej postaci [4]. 


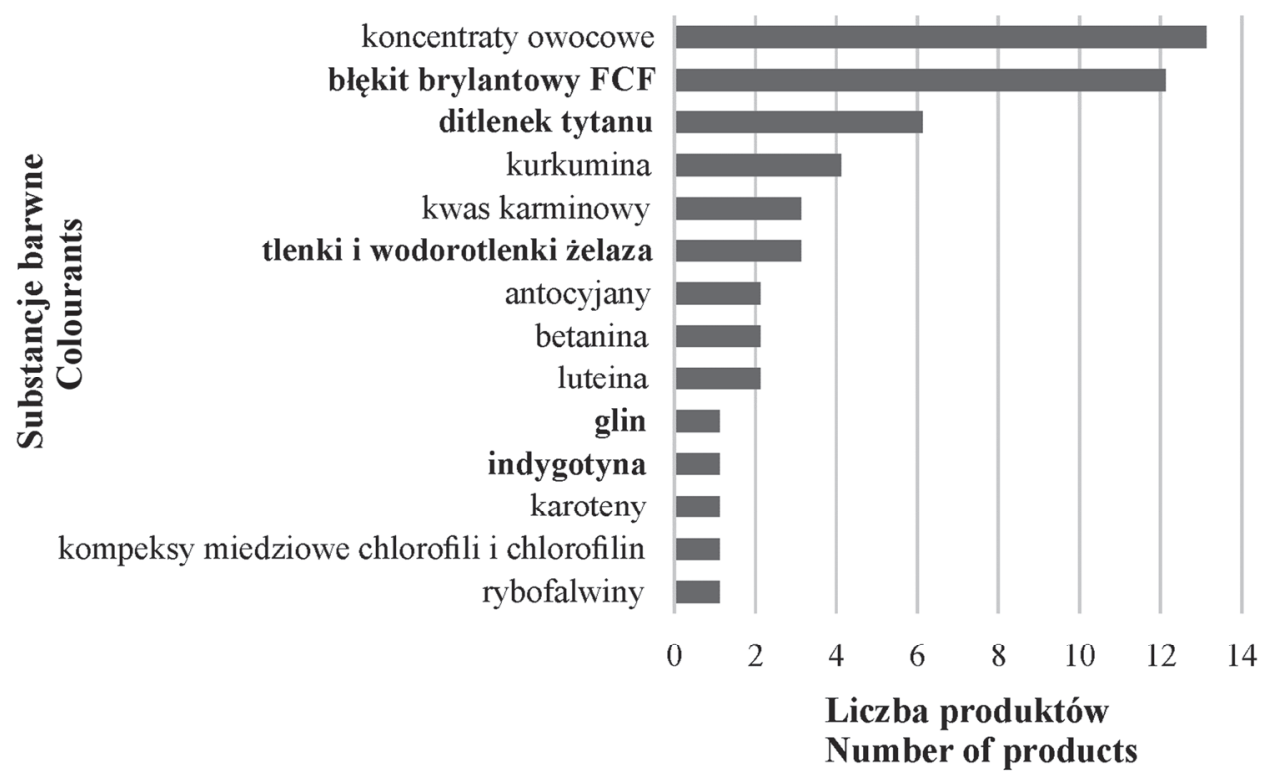

Objaśnienia / Explanatory notes:

koncentraty owocowe / fruit concentrates; kwas karminowy / carminic acid; tlenki i wodorotlenki żelaza / iron oxides and hydroxides; glin / aluminium; ryboflawiny / riboflavines. Pozostałe objaśnienia jak pod rys. 1. i 4. / Other explanatory notes as in Fig. 1. and 4.

Rys. 5. Rodzaje barwników i liczba badanych dekoracji cukierniczych z deklarowanym przez producentów użyciem tych barwników

Fig. 5. Types of colourants and number of analysed confectionery decorations in which, acc. to manufacturers' declarations, those colourants were used

Tabela 1. Charakterystyka barwników deklarowanych w badanych produktach $\mathrm{z}$ wyłączeniem barwników syntetycznych i nieorganicznych

Table 1. Profile of colourants declared in analysed products excluding synthetic and inorganic colourants

\begin{tabular}{||l|l|l||}
\hline \multicolumn{1}{|c|}{$\begin{array}{c}\text { Barwnik } \\
\text { Colourant*) }\end{array}$} & \multicolumn{1}{|c|}{ Pochodzenie / Origin [20] } & \multicolumn{1}{c|}{$\begin{array}{c}\text { Charakterystyka barwnika } \\
\text { Profile of colourant [20] }\end{array}$} \\
\hline $\begin{array}{l}\text { Kurkumina, E100 } \\
\text { (diaryloheptanoidy, } \\
\text { polifenole)/Curcumin, } \\
\text { E 100 diarylheptanoids, } \\
\text { polyphenols) }\end{array}$ & $\begin{array}{l}\text { ekstrakcja kłączy ostryżu długiego } \\
\text { (Curcuma longa) / obtained by } \\
\text { turmeric rhizomes extraction (Cur- } \\
\text { cuma longa) }\end{array}$ & $\begin{array}{l}\text { źółty do pomarańczowego, wrażli- } \\
\text { wy na utlenianie / yellow to orange, } \\
\text { sensitive to oxidation }\end{array}$ \\
\hline $\begin{array}{l}\text { Ryboflawina, wit. } \mathrm{B}_{2}, \\
\text { E101 (flawiny) } \\
\text { Riboflavins, vit. } \mathrm{B}_{2}, \\
\text { E101 (flavins) }\end{array}$ & $\begin{array}{l}\text { występuje w warzywach, produko- } \\
\text { wana mikrobiologicznie } \\
\text { occurs in vegetables, produced }\end{array}$ & żółty / yellow \\
microbiologically & \\
\hline
\end{tabular}




\begin{tabular}{|c|c|c|}
\hline $\begin{array}{l}\text { Kwas karminowy, } \\
\text { koszenila, karminy, } \\
\text { E120 (antrachinony) } \\
\text { Carminic acid, cochi- } \\
\text { neal, carmines, E120 } \\
\text { (antraquinones) }\end{array}$ & $\begin{array}{l}\text { pozyskiwany z owadów Dactylo- } \\
\text { pius coccus cacti. Głównym skład- } \\
\text { nikiem barwnika jest kwas karmi- } \\
\text { nowy / obtained from Dactylopius } \\
\text { coccus Cacki insects. Main ingre- } \\
\text { dient of colourant is carminic acid }\end{array}$ & $\begin{array}{l}\text { ciemnoczerwony; zanieczyszczenia } \\
\text { mogą powodować wstrząs anafilak- } \\
\text { tyczny, a także katar sienny oraz } \\
\text { pokrzywkę / dark red; impurities } \\
\text { can cause anaphylactic shock as } \\
\text { well as hay fever and urticaria }\end{array}$ \\
\hline $\begin{array}{l}\text { Chlorofile i chlorofili- } \\
\text { ny, E140 (porfiryna) } \\
\text { Chlorophylls and chlo- } \\
\text { rophyllins, E } 140 \text { (por- } \\
\text { phyrins) }\end{array}$ & $\begin{array}{l}\text { ekstrakcja materiału roślinnego; } \\
\text { chlorofiliny są produktami hy- } \\
\text { drolizy grup estrowych w chlorofilu } \\
\text { extraction of plant material; chloro- } \\
\text { phyllins are products of ester } \\
\text { groups hydrolysis in chlorophyll }\end{array}$ & $\begin{array}{l}\text { zielony, znaczenie mają chlorofile a } \\
\text { i b; nie otrzymuje się ich w postaci } \\
\text { czystej ze względu na brak stabil- } \\
\text { ności; chlorofiliny mają barwy } \\
\text { intensywniejsze od chlorofilu } \\
\text { green; a and b chlorophylls are of } \\
\text { importance; they are not obtained in } \\
\text { pure form due to lack of stability; } \\
\text { chlorophyllins have more intense } \\
\text { colours than chlorophyll }\end{array}$ \\
\hline $\begin{array}{l}\text { Kompleksy miedziowe } \\
\text { chlorofili i chlorofilin, } \\
\text { E141 (porfiryna) } \\
\text { Copper complexes of } \\
\text { chlorophylls and chlo- } \\
\text { rophyllins, E } 141 \text { (por- } \\
\text { phyrins) }\end{array}$ & $\begin{array}{l}\text { półsyntetyczne pochodne chlorofi- } \\
\text { lu, w których jon magnezu został } \\
\text { zastąpiony miedzią, a grupy kar- } \\
\text { boksylowe występują w postaci soli } \\
\text { sodowych / semi-synthetic chlo- } \\
\text { rophyll derivatives in which ma- } \\
\text { gnesium ion has been replaced with } \\
\text { copper, and carboxyl groups are in } \\
\text { the form of sodium salts }\end{array}$ & $\begin{array}{l}\text { formy bardziej stabilne i trwałe niż } \\
\text { kompleks z magnezem; miedź nie } \\
\text { jest uwalniana w przewodzie po- } \\
\text { karmowym i nie jest szkodliwa } \\
\text { more stable and durable forms than } \\
\text { complex with magnesium; copper is } \\
\text { not released in the digestive tract } \\
\text { and is not harmful }\end{array}$ \\
\hline $\begin{array}{l}\text { Karmel amoniakalno- } \\
\text { siarczynowy, E150d } \\
\text { Sulphite ammonia } \\
\text { caramel, E150d }\end{array}$ & $\begin{array}{l}\text { otrzymywany w wyniku ogrzewa- } \\
\text { nia węglowodanów } \\
\text { obtained through heating carbohy- } \\
\text { drates }\end{array}$ & $\begin{array}{l}\text { ciemnobrązowy do czerwonego; } \\
\text { w zależności od substratu może } \\
\text { zawierać alergeny / dark brown to } \\
\text { red; depending on the substrate, it } \\
\text { may contain allergens }\end{array}$ \\
\hline $\begin{array}{l}\text { Węgiel roślinny, E153 } \\
\text { Vegetable carbon, E153 }\end{array}$ & $\begin{array}{l}\text { zwęglanie materiału roślinnego } \\
\text { charring of plant material }\end{array}$ & czarny / black \\
\hline $\begin{array}{l}\text { Karoteny; beta-karoten, } \\
\text { E160a (tetraterpeny) } \\
\text { Carotenes; beta- } \\
\text { carotene, E160a (tetra- } \\
\text { terpenes) }\end{array}$ & $\begin{array}{l}\text { otrzymywany z roślin, alg i grzy- } \\
\text { bów; beta-karoten syntetyczny jest } \\
\text { identyczny z naturalnym } \\
\text { isolated from plants, algae, and } \\
\text { fungi; synthetic beta-carotene is } \\
\text { identical to the natural one }\end{array}$ & $\begin{array}{l}\text { żółty do pomarańczowego / yellow } \\
\text { to orange }\end{array}$ \\
\hline $\begin{array}{l}\text { Beta-apo-8'-karotenal, } \\
\text { E160e (triterpeny) } \\
\text { Beta-apo-8'-carotenal, } \\
\text { E160e (triterpenes) }\end{array}$ & $\begin{array}{l}\text { wyodrębniany z roślin lub wytwa- } \\
\text { rzany z karotenu / isolated from } \\
\text { plants or produced from arotene }\end{array}$ & $\begin{array}{l}\text { pomarańczowo-czerwony / orange- } \\
\text { red }\end{array}$ \\
\hline $\begin{array}{l}\text { Luteina, E161b (tetra- } \\
\text { terpeny) } \\
\text { Lutein, E161b (tetrater- } \\
\text { penes) }\end{array}$ & $\begin{array}{l}\text { ekstrakcja z materiału roślinnego } \\
\text { extraction from plant material }\end{array}$ & żółty / yellow \\
\hline $\begin{array}{l}\text { Betanina, czerwień } \\
\text { buraczana, E162 (po- } \\
\text { chodna indolu) }\end{array}$ & $\begin{array}{l}\text { otrzymywany z buraka ćwikłowego } \\
\text { obtained from beetroot }\end{array}$ & $\begin{array}{l}\text { ciemnoczerwony; wydalany z } \\
\text { organizmu z moczem, ale niezale- } \\
\text { cany dla dzieci w związku z obec- } \\
\text { nością azotanów / dark red; comple- }\end{array}$ \\
\hline
\end{tabular}




\begin{tabular}{||l|l|l||}
\hline $\begin{array}{l}\text { Betanin, Beetroot Red, } \\
\text { E 162 (indole deriva- } \\
\text { tive) }\end{array}$ & $\begin{array}{l}\text { tely excreted from the body with } \\
\text { urine, but not recommended for } \\
\text { children due to the presence of } \\
\text { nitrates }\end{array}$ \\
\hline $\begin{array}{l}\text { Antocyjany, E163 } \\
\text { (flawonoidy) }\end{array}$ & $\begin{array}{l}\text { ekstrakcja z materiału roślinnego, } \\
\text { np. czerwonej kapusty lub skórek } \\
\text { winogron / extraction from plant } \\
\text { material, e.g. red cabbage or grape } \\
\text { (flavonoids) }\end{array}$ & $\begin{array}{l}\text { pomarańczowy do fioletowego - } \\
\text { duży zakres barw; barwa zależy od } \\
\mathrm{pH} / \text { large range of colours from } \\
\text { skins } \\
\mathrm{pH}\end{array}$ \\
\hline
\end{tabular}

Objaśnienie / Explanatory note:

*) - w nawiasie podano grupę związków chemicznych, do której zalicza się barwnik / chemical category of different biocolourants in parentheses

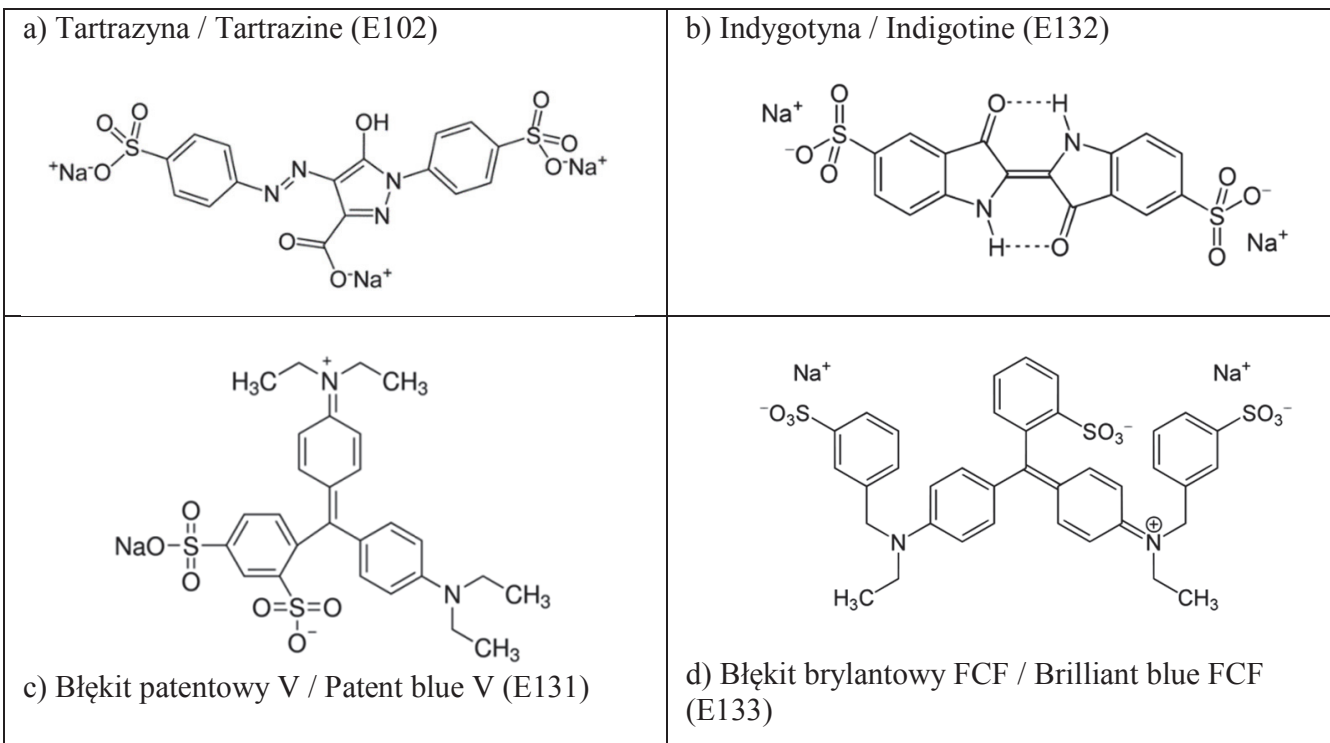

Rys. 6. Wzory chemiczne tartrazyny, jako przykładowego barwnika azowego (a), oraz omawianych barwników syntetycznych (b, c, d)

Fig. 6. Chemical structures of tartrazine as exemplary (a) azo colourant and of discussed synthetic colourants $(b, c, d)$

\section{Wnioski}

1. Według deklaracji producentów w produktach przeznaczonych dla dzieci stosowane są przede wszystkim ekstrakty i koncentraty pochodzenia roślinnego, ewentualnie barwniki naturalne bądź identyczne z naturalnymi.

2. Zadeklarowano obecność jedynie trzech organicznych barwników syntetycznych, przy czym żaden z nich nie należy do grupy „barwników z Southampton”. Poza 
dekoracjami cukierniczymi występowały one w sumie w 6 ze 107 analizowanych produktów.

3. Obecność syntetycznych barwników organicznych zadeklarowano natomiast w prawie $80 \%$ dekoracji cukierniczych. Nie są to jednak produkty o tak powszechnym spożyciu jak żelki czy lizaki.

4. Godne podkreślenia jest to, że producenci nie deklarowali stosowania tartrazyny do barwienia produktów dla dzieci, mimo że związek ten jest używany do barwienia produktów na kolor zielony.

\section{Literatura}

[1] Białecka-Florjańczyk E., Kapturowska A., Stolarzewicz I.: Mikrobiologiczne źródła barwników w technologii żywności. Postępy Mikrobiol., 2012, 3,167-176.

[2] Bateman B., Warner J.O., Hutchinson E., Dean T., Rowlandson P., Gant C., Grundy J., Fitzgerald C., Stevenson J.: The effects of a double blind, placebo controlled, artificial food colourings and benzoate preservative challenge on hyperactivity in a general population sample of preschool children. Arch. Dis. Child., 2004, 89, 506-511.

[3] Chung K.-T., Stevens S.E., Cerniglia C.E.: The reduction of azo dyes by the intestinal microflora. Crit. Rev. Microbiol., 1992, 18 (3), 175-190.

[4] EFSA: Scientific opinion on the re-evaluation of Brilliant Blue FCF (E133) as a food additive. EFSA J., 2010, 8 (11), \#1853.

[5] EFSA: Scientific opinion on the re-evaluation of Patent Blue V (E131) as a food additive. EFSA J., 2013, 11(3), \#2818.

[6] EFSA: Scientific opinion on the re-evaluation of Indigo Carmine (E132) as a food additive. EFSA J., 2014, 12(7), \#3768.

[7] Feingold B.F.: Hyperkinesis and learning disabilities linked to artificial food flavors and colors. Am. J. Nurs., 1975, 75, 797-780.

[8] Feketea G., Tsabour S.: Common food colorants and allergic reactions in children: Myth or reality? Food Chem., 2017, 230, 578-588.

[9] FAO/WHO: Food additives summary and conclusions. 82 ${ }^{\text {nd }}$ Joint FAO/WHO Expert Committee on Food Additives (JECFA) Meeting, Geneva, Switzerland, 2016, June, 7-16.

[10] Gajda-Wyrębek J., Jarecka J., Kuźma K., Beresińska M.: Zawartość barwników mających szkodliwy wpływ na aktywność i skupienie uwagi u dzieci w wybranych środkach spożywczych. Bromat. Chem. Toksykol., 2011, XLIV (3), 760-767.

[11] Gajda-Wyrębek J., Jarecka J., Kuźma K., Mirowska M., Karłowski K.: Bezpieczeństwo barwników stosowanych w produkcji żywności. Przem. Spoż., 2010, 7/8, 52-54.

[12] Gasik A., Mitek M.: Syntetyczne barwniki organiczne w technologii żywności. Przem. Spoż., 2007, 8, 48-53.

[13] Kanarek R.B.: Artificial food dyes and attention deficit hyperactivity disorder. Nutr. Rev., 2011, 69 (7), 385-391.

[14] König J.: Food colour additives of synthetic origin. In: Colour Additives for Foods and Beverages. Ed. M. Scotter. Elsevier, Cambridge 2015, pp. 35-60.

[15] Matouq M., Al-Anber Z., Susumu N., Tagawa T.: The kinetic of dyes degradation resulted from food industry in wastewater using high frequency of ultrasound. Sep. Purific. Technnol. 2014, 135, $42-47$. 
[16] McCann D., Barrett A., Cooper A., Crumpler D., Dalen L., Grimshaw K., Kitchin E., Lok K., Porteous L., Prince E., Sonuga-Barke E., Warner J.O., Stevenson J.: Food additives and hyperactive behaviour in 3-year-old and 8/9-year-old children in the community: A randomised, double-blinded, placebo-controlled trial. Lancet, 2007, 370 (9598), 1560-1567.

[17] Mortensen A.: Carotenoids and other pigments as natural colorants. Pure Appl. Chem., 2006, 78(8), 1477-1491.

[18] Oplatowska-Stachowiak M., Elliott C.T.: Food colors: Existing and emerging food safety concerns. Crit. Rev. Food Sci. Nutr., 2017, 57 (3), 524-548.

[19] Rozporządzenie Parlamentu Europejskiego i Rady (WE) nr 1333/2008 z dnia 16 grudnia 2008 r. w sprawie dodatków do żywności. Dz. Urz. UE L 354, s. 16, z 31.12.2008.

[20] Rutkowski A., Gwiazda S., Dąbrowski K.: Barwniki. W: Kompendium dodatków do żywności. Hortimex, Konin 2003, ss. 307-348.

[21] EFSA: Scientific opinion on the re-evaluation Tartrazine (E102). EFSA J., 2009, 7(11), \#1331.

[22] Silbergeld E.K., Anderson S.M.: Artificial food colors and childhood behavior. Bull N.Y. Acad. Med., 1982, 58, 275-295.

[23] Solymosi K., Latruffe N., Morant-Manceau A., Schoefs B.: Food colour additives of natural origin. In: Colour Additives for Foods and Beverages. Ed. M. Scotter. Elsevier, Cambrige 2015, pp. 3-34.

\section{FOOD COLOURANTS IN PRODUCTS FOR CHILDREN BASED ON MANUFACTURERS' DECLARATIONS}

\section{$\mathrm{S} u \mathrm{~mm}$ a r y}

Colourants used in food products can be divided into natural and synthetic colourants. The use of the latter raises many controversies because of their potentially harmful effect on human body. Of particular concern is the disadvantageous effect of artificial colourants on the behaviour and health of children. The objective of the study was to assess the composition of some selected products for children with regard to the colourants applied. Colourific compounds used in the sweets and beverages for children were reviewed based on the manufacturer's declarations covering 107 products designed for children including beverages, jellies, lollipops, candies, and confectionery decorations. The results were discussed in the context of the toxicity of colourants applied in the food industry. Moreover, a brief description of the colouring substances found in the products analysed was presented with particular focus on the synthetic compounds.

It was found that the manufacturers of the analysed products for children used, primarily, extracts and concentrates of plant origin, and alternatively natural colourants or those identical with the natural compounds. The use of synthetic colourants is limited as recommended by the European Food Safety Authority (EFSA). As declared by the manufacturers of the food products for children on the labels thereon, none of the three organic synthetic colourants belonged to a "Southampton Six" group. This name is given to some colourants (quinoline yellow - E104, tartrazine - E102, FCF sunset yellow - E110, carmoisine - E122, ponceau 4R - E124, allura red AC - E129) in respect of whom there are grounds for believing that their effect on the activity and attention in children is disadvantageous.

Key words: products for children, natural and synthetic food colourants, safety assessment, manufacturers' declarations on labels 